\title{
Business Center construction project as the sustainable development model
}

\author{
Veronika Luchkina * \\ Moscow State University of Civil Engineering, 129377, Moscow, Russia
}

\begin{abstract}
Sustainable development means the ability of an object to maintain the required level of environmental, social and economic indicators while meeting the needs of not only the living, but also future generations. These standards suggest using a uniform estimated figure that considers economic, environmental and social indicators. Design with resource-saving technologies has become an important part of the developed Terms of Reference for the project, and environmental friendliness has become a key element of the business center marketing strategy. The research is aimed at developing a business center construction project as a sustainable development model. The research results are the following tasks: to perform calculations on the total cost of the building's life cycle; perform the project economic efficiency assessment; consider technical solutions for power consumption systems, building heat supply and water consumption systems; analyze the sustainability of the project environment; identify the risk levels for the business center construction project development. The research itself develops a concept for the project implementation, project risk analysis was carried out, the categories for assessing the environmental sustainability were compared with possible technical solutions of the project construction. There were also considered technical characteristics on internal and external lighting, heat supply of the building, water treatment and re-use, and energy-efficient elevators. The conducted risk assessment revealed a low cumulative risk of this construction project development. With the factored level of incomes and expenses, the project can be recognized as efficient. Further research matters can be issues of a detailed study at the level of a comprehensive ESG risk assessment of contemporary construction companies.
\end{abstract}

\section{Introduction}

With a view to ensure environmental safety and to prevent negative environmental impact on a national scale, a uniform strategy of state policy in this area is usually developed. Its main goal is to protect the environment and ensure the efficient use of natural resources. In Russia, the document that is called "Basic Principles of State Policy of in the Field of Environmental Development of Russia for the period up to 2030" was approved by the President of the Russian Federation on April 30, 2012. It considers the major directions of

*Corresponding author: luchkinavv@mail.ru 
the state activities in the field of environmental safety in relation to various fields of activity, including construction. In case of planning the construction of large-scale facilities, a preliminary procedure for assessing the facility environmental impact is to be performed even prior to the start of the project design stage.

A number of state standards has recently been issued in our country, which detail the principles of sustainable development in construction and analyze the requirements for the procedures and methods that are advisable to apply while assessing the development sustainability in this field. These regulations are similar to the European standards of the EN 15643 series. Practically speaking, foreign standards of this series are intended to determine the sustainable development indexes throughout the entire life cycle of the facility under construction.

The concept of "life cycle" is also widely used in construction practices in our country. In the construction sector, such cycle usually includes pre-design studies, engineering surveys, design work, construction and operation of the facility, followed by the disposal at the end of its service life.

In foreign documents sustainable development as a rule means the ability of an object to maintain the required level of environmental, social and economic indicators while meeting the needs of not only the living, but also future generations. Therefore, these standards suggest using a uniform estimated figure that considers the above-mentioned economic, environmental and social indicators. It is called an integrated index of sustainable development.

Having studied the development of the office services market in Moscow, the researchers decided to develop a project of the office business center for the purposes of commercial profit from rent. Design with resource-saving technologies has become an important part of the Terms of Reference for the project. Environmental friendliness has become a key element of the business center marketing strategy: the name, logo, facade and entry elements finish - all these should remind future users of the green principles of the building construction and management. The project stands out in terms of perception of the environmental friendliness as a key element of the market positioning [1].

The purpose of research was to develop the business center construction project as the sustainable development model. On the basis of the expert assessment, the preliminary extra costs arising from the construction budget increase due to certification were calculated. The exceedance of the base construction budget in the implementation of the solutions prescribed by the green standard makes about 16\% (approx. $200 \mathrm{USD} / \mathrm{sq} . \mathrm{m}$ of the building area). At that $10 \%$ of extra costs (that is $20 \mathrm{USD} / \mathrm{sq} . \mathrm{m}$ ) will be made of additional surveys and consulting [2].

The research results are the following tasks:

- calculations of the entire life cycle cost of the building were analyzed and performed;

- economic assessment of the project efficiency was performed;

- there were considered technical characteristics on internal and external lighting, heat supply of the building, water treatment and re-use, and energy-efficient elevators;

- the categories of assessing environmental sustainability were compared with possible technical solutions for the project construction;

- risk levels for the business center construction project development were identified.

\section{Materials and Methods}

To meet the consumer demand among population and guests of the city at the highest level, the project provides for creation of the office center of A-Class. The building consists of two linked rectangular blocks of different height. Block " $\mathrm{A}$ " is a 22 -storey tower office building with a spacious double-height lobby, cafe, bank office and guard. Block " $\mathrm{B}$ " is a 
5-storey multi-purpose unit with a 40-room hotel and fitness club. The adjacent territory will include a surface car parking, underroof bicycle parking and electric vehicle charging station, as well as relax and recreation area for the building users and local residents. The business center is supposed to be located within walking distance of the metro station and public transport stops.

The research studied and analyzed the standards of sustainable development in construction recently published in our country, such as:

- GOST R 57274.1-2016/EN 15643-1: 2010 "Sustainable development in construction. Part 1. General provisions";

- GOST R 57274.2-2016/EN 15643-2:2011 "Sustainable development in construction. Part 2. Principles of the environmental performance evaluating";

- GOST R 57274.3-2016/EN 15643-3:2012 Sustainable development in construction. Part 3. Principles of the social performance evaluating";

- GOST R 57274.4-2016/EN 15643-4:2012 "Sustainable development in construction. Part 4. Principles of the economic indicators assessment".

All the above regulations consider environmental, social and economic indicators of sustainable development in construction.

The research also studied and analyzed the process of assessing sustainable development, including consideration of such documents as assessing the risk levels of a project using the method of the European Bank for Reconstruction and Development (EBRD) and assessing the environment sustainability according to the methodology by STO NOOSTROY 2.35.4-2011 "Green Construction".

In the course of research, the calculations of the entire life cycle cost of the building were analyzed and performed. The following technical characteristics on internal and external lighting, heat supply of the building, water treatment and re-use, and energyefficient elevators were considered. The research itself develops a project concept, performs the project efficiency assessment, the categories for assessing the environment sustainability were compared with possible technical solutions of the project construction.

\section{Discussion}

In the course of research, the calculations of the entire life cycle cost of the building were analyzed and performed. The following technical characteristics on internal and external lighting, heat supply of the building, water treatment and re-use, and energy-efficient elevators were considered. The project comprises the land improvement plan for the adjacent territory, including introduction of the "green" roof technology into operation [3].

It is planned to have separate accounting of the energy, water and heat by various lessees, floors and functional areas of the business center. The readings will be recorded by the automated control and dispatch system of the building. This will make it possible to conduct a detailed results analysis, keep statistics and set the goals to reduce resources consumption. The conditions for separated waste collection are created in the building. There is a designated area for several containers for each waste group. Also, a waste compactor will be installed to increase the container filled density (by 5-7 times more than in the normal storage) and reduce the frequency of the waste removal for further processing.

Data on the capabilities of resource saving for the construction of a business center is summarized in Table 1 [4].

Table 1. Resource saving potential of a business center construction project

\begin{tabular}{|l|l|l|}
\hline Consumable resource & Techical solution & Resource saving potential \\
\hline Power consumption system & Energy consumption dispatch & Reduction of power \\
\hline
\end{tabular}




\begin{tabular}{|l|l|l|}
\hline & $\begin{array}{l}\text { (Energy-efficient lamps, } \\
\text { energy-efficient elevators } \\
\text { KONE) }\end{array}$ & consumption by 20-35\% \\
\hline Building heat supply & $\begin{array}{l}\text { Heat consumption dispatch } \\
\text { (Vitomax three-course hot } \\
\text { water boilers) }\end{array}$ & $\begin{array}{l}\text { All the equipment has } 100 \% \\
\text { redundancy }\end{array}$ \\
\hline Thermal acceptability & $\begin{array}{l}\text { Argon-filled insulating glass } \\
\text { units; thermostatic heads on } \\
\text { heating radiators, fan coil units }\end{array}$ & $90 \%$ of all premises \\
\hline Water consumption system & $\begin{array}{l}\text { Water consumption dispatch } \\
\text { (valves in bathrooms; system } \\
\text { for water treatment and re-use } \\
\text { at the car wash facility, surface } \\
\text { runoff treatment facilities) }\end{array}$ & $\begin{array}{l}\text { Reduction of consumption } \\
\text { by 55\% }\end{array}$ \\
\hline Visual acceptability & $\begin{array}{l}\text { Site improvement, green roof } \\
\text { technologies }\end{array}$ & Air pollution reduction \\
\hline
\end{tabular}

In the course of the concept development, the calculations of the full life cycle cost of the building were made. The operating expenses (utility fees, maintenance and repair, administrative management) are expected to make $75 \%$ of the full life cycle cost of the building. The utility fees will make only $10 \%$ of the project costs that greatly differs from similar projects abroad with 30-40\% accounted for this indicator [5].

In the course of the research, the economic efficiency of the business center construction project was assessed. With the factored level of incomes and expenses, the project can be recognized as efficient. The financial plan is executed for the 10-year prospect [6]. The investment idea under consideration is characterized by the following indicators:

- the first payback period of the total investment costs without considering the construction period makes about 6.30 years;

- the discounted payback period taking into account the effective percentage rate of $10 \%$ per annum makes about 10.4 years from the start of the project implementation.

\section{Conclusions}

The very assessment of the environment sustainability is performed by experts according to the methodology of STO NOOSTROY 2.35.4-2011 "Green construction" [7]. The table presents a preliminary analysis of the project environment sustainability, based on the developed assessment criteria and indicators. (Table 2).

Table 2. Project environment sustainability analysis

\begin{tabular}{|c|l|}
\hline Category & \multicolumn{1}{|c|}{ Project techical solution } \\
\hline $\begin{array}{c}\text { External environment acceptability and } \\
\text { quality }\end{array}$ & $\begin{array}{l}\text { Site improvement, green roof technologies, } \\
\text { roofed bicycle parking, charging station for } \\
\text { electric vehicles, public transport accessibility }\end{array}$ \\
\hline Facility architectural and layout quality & $\begin{array}{l}\text { Building compatibility with surrounding } \\
\text { buildings; in the daytime, the artificial lighting } \\
\text { of the staircase in the areas with daylight } \\
\text { switches off automatically. Green roof } \\
\text { technologies, car parking lots availability. }\end{array}$ \\
\hline Internal environment acceptability and \\
ecology & $\begin{array}{l}\text { The internal lighting of public areas will be } \\
\text { provided by energy-efficient LEDs. The control } \\
\text { is provided by the motion and light sensors. }\end{array}$ \\
\hline
\end{tabular}




\begin{tabular}{|c|c|}
\hline & $\begin{array}{l}\text { Argon-filled insulating glass units. } \\
\text { Thermostatic heads on heating radiators, fan } \\
\text { coil units }\end{array}$ \\
\hline $\begin{array}{l}\text { Quality of sanitary protection and waste } \\
\text { disposal }\end{array}$ & $\begin{array}{l}\text { Car wash using water treatment and re-use } \\
\text { system. The contaminated water discharge to } \\
\text { the urban water disposal system is completely } \\
\text { excluded. Surface runoff treatment facilities } \\
\text { with a five-tier treatment. Separate waste } \\
\text { collection organizations. Compactor press for } \\
\text { increasing the filling density of containers. }\end{array}$ \\
\hline Efficient water use & $\begin{array}{l}\text { Water consumption dispatch (valves in } \\
\text { bathrooms; system for water treatment and re- } \\
\text { use at the car wash facility) } \\
\text { Planned consumption reduction by } 55 \%\end{array}$ \\
\hline Energy-saving and energy efficiency & $\begin{array}{l}\text { Energy consumption dispatch (Energy-efficient } \\
\text { lamps, } \\
\text { energy-efficient elevators KONE) All the } \\
\text { equipment of the individual heat supply facility } \\
\text { have the } 100 \% \text { redundancy that, in addition to } \\
\text { ensuring the reliable operation, provides for } \\
\text { maintenance without complete switch-off. } \\
\text { Reduction of power consumption by } 20-35 \%\end{array}$ \\
\hline Use of alternative and renewable energy & Use of secondary energy resources \\
\hline $\begin{array}{l}\text { Ecology of the creation, operation and } \\
\text { disposal of the facility }\end{array}$ & $\begin{array}{l}\text { Terms of reference, given the BREEAM } \\
\text { requirements, a water treatment and re-use } \\
\text { system at the car wash facility, car wash using a } \\
\text { water treatment and re-use system. The } \\
\text { contaminated water discharge to the urban } \\
\text { water disposal system is completely excluded. } \\
\text { Surface runoff treatment facilities with a five- } \\
\text { tier treatment. }\end{array}$ \\
\hline Economic efficiency & $\begin{array}{l}\text { The first payback period of the total investment } \\
\text { costs without taking into account the } \\
\text { construction period makes about } 6.30 \text { years; } \\
\text { - the discounted payback period taking into } \\
\text { account the effective percentage rate of } 10 \% \\
\text { per annum makes about } 10.4 \text { years from the } \\
\text { start of the project implementation. }\end{array}$ \\
\hline $\begin{array}{l}\text { Quality of the project development and } \\
\text { management }\end{array}$ & $\begin{array}{l}\text { It is planned to engage experienced designers } \\
\text { and developers in the field of "green } \\
\text { construction" }\end{array}$ \\
\hline
\end{tabular}

According to the document issued by the European Bank for Reconstruction and Development (EBRD), there was conducted a risk assessment of the project under development (Section F Construction)(Table 3). Pursuant to this procedure, after reviewing the results of the facility's environmental impact analysis, the bank shall decide on the possibility of providing financial support to the project implementation [8].

Table 3. Risk levels for the business center construction project development

\begin{tabular}{|l|l|l|}
\hline Environmental risk & Social risk & Cumulative risk \\
\hline low & low & low \\
\hline
\end{tabular}

For the global investment and financial community, the introduction of ESG (Environmental, Social, Governance) principles into their investment strategies has become 
mainstream in recent years. Compliance with the ESG principles implies the integration of the best practices in such areas as Environmental, Social (social policy) and Governance into the strategy and business of the company. The ideological basis of these practices was developed about 15 years ago by the UN in the form of the Principles of Responsible Investment.

ESG ratings serve as a benchmark in assessing the efficiency and consistency of adherence to these principles. Investors consider them when deciding on investments into a particular enterprise.

No important investment decision has been made without considering social and environmental risks. The number of companies (including banks, pension and investment funds) that signed the UN Principles of Responsible Investment (UNPRI) in 2019 exceeded 2,300 , while the volume of assets under their management reached 86 trillion USD. The total volume of green bond issues in the world last year exceeded \$ 258 billion. In January 2020, the world's largest asset manager, Black Rock, became a signatory to the Climate Action 100+ initiative, which means higher likelihood of refocusing of their portfolio worth over $\$ 7$ trillion USD to the more environmentally sustainable investments.

The foretype of an independent ESG navigation system for Russia is already in place. For the second year, the European ranking agency RAEX-Europe (Rating-Agentur Expert $\mathrm{RA} \mathrm{GmbH}$ ) has been compiling a unique ESG rating of Russian regions, which makes it possible to assess environmental and social risks, as well as the quality of public administration, within a single scale. This year, the Top-3 of the rating included Tatarstan (Republic of Tatarstan), Moscow (the city of Moscow) and Lipetsk region.

In terms of the budget, the most expensive environmental program adopted under the program presidential decree dated May 2018 is "Clean Air". 499.83 billion rubles will be spent for this program over the next six years. In second place is taken by the development of an integrated waste management system worth 404 billion rubles, while the "Rehabilitation of the Volga River" is ranked third with the cost of 220 billion rubles.

The ranking provides not only to rate the regions by the level of a comprehensive ESG risk assessment, but also makes it possible to assess the readiness of the regions for the economic crisis caused by COVID-19 and oil prices fall. Further research items can be issues of a detailed study of the level of a comprehensive assessment of ESG risks of contemporary construction companies, for the further development of a methodology to ensure the sustainable development of construction projects.

\section{References}

1. V.V. Luchkina Optimization of the project of energy efficient construction and the analysis of the market of energy efficient technologies at design of buildings System technologies 28, 5-12 (2018)

2. V.V. Luchkina Analysis of application of "green" roof technologies as objects of improvement Prospects of science 12(123), 147-150 (2019)

3. V.V. Luchkina, IOP Conf. Series: Earth and Environmental Science 90, 1-6 (2017)

4. V. Luchkina, Materials Science Forum 945, 1043-1046 (2019)

5. V. Luchkina, E3s Web of Conferences 97, 01037 (2019)

6. V. Luchkina, E3s Web Conf. 110, 01083 (2019)

7. S. Sinenko, T. Poznakhirko, MATEC Web of Conferences 193, 05011 (2018)

8. R. Kazaryan, D. Pogodin, E3S Web of Conferences, FORM-2019 97, 04002 (2019) 